\title{
Consumption of light products and prevalence of Obesity among a population of Academics in Casablanca, Morocco
}

\author{
Houriya Mestaghanmi ${ }^{1}$, Ali Labriji ${ }^{2}$, Soufi Kaoutar ${ }^{3}$., Fatima Zahra Kehailou ${ }^{1}$, Martaj ${ }^{1}$ Mehdi., \\ Imane M'Touguy ${ }^{1}$, Mohammed Jabari ${ }^{4}$, Souad El Amrani ${ }^{5}$.
}

1. Department of Biology. Physiopathology and Cellular Genetics Laboratory, Metabolism Nutrition Toxicology Team. Hassan II University of Casablanca. Ben M'Sik Faculty of Sciences, B P.7955 Sidi-

Othmane, Casablanca, Morocco

2. Department of Computer Mathematics. Laboratory Modeling Analysis and Simulation. Ben M'Sik

Faculty of Sciences. Casablanca. Morocco. alilabriji@gmail.com

3. Biology and Health Laboratory. Department of Biology. Hassan II University of Casablanca. Ben M'Sik Faculty of Sciences

B P.7955 Sidi-Othmane, Casablanca, Morocco. kaoutar.075@ @otmail.fr

4. Hygiene, Prevention and Environment Division of Casablanca. Hygiene Service of the Sidi-Othmane

District. Boulevard El Joulane. Casablanca. Morocco.

5. Department of Biology. Hassan II University of Casablanca. Ben M'Sik Faculty of Sciences, Laboratory of Ecology and Environment, Casablanca. Morocco.

\begin{abstract}
Moroccan citizens are increasingly aware of the effect of food on their health. The objective of this work is to study the consumption of Light products (LP) by students, as well as their effects on the prevalence of obesity.

A descriptive cross-sectional study was carried out in 2017 using an anonymous questionnaire. The latter included information related to Gender, age, anthropometric parameters, perception of the body image, as well as the consumption of BP (types, frequency, duration, reasons for consumption, etc.). The results were analyzed by SPSS software, version 21.

$19.9 \%$ of respondents never consume light products, $59.2 \%$ consume them sometimes, $18.6 \%$ daily. This consumption varies according to Gender ( $p$ <0.05). 28.7\% of students consume them to slim down; $30.3 \%$ think they are the best for good health and $12 \%$ like their good taste.

$47.5 \%$ of the respondents consume LP in sugar and $30.3 \%$ the reduced in fat, with a significant difference between the two gender ( $p$ <0.05). Dairy products are the most consumed by participants $(48.7 \%)$ among the fatty acids, while those for sugar, the most consumed are: confectionery (32.3\%) and light drinks (23\%).

$61.66 \%$ of LP consumers have a normal weight (37.9\% consume them sometimes and $23.76 \%$ daily); $29.66 \%$ are overweight (19\% sometimes consume them and $10.6 \%$ daily) and $4.45 \%$ moderate obesity (2.9\% sometimes and $1.5 \%$ daily). $60 \%$ of consumers of low fatty acids and $0.3 \%$ of consumers of low sugar have moderate obesity.

Uncontrolled consumption of LP can increase the risk of overweight and obesity. However, these products can be consumed as part of a healthy diet and preferably in combination with a balanced and varied diet.
\end{abstract}

Keywords: Students, Light Products, Body Image Satisfaction, Body Mass Index, Obesity.

\section{INTRODUCTION}

Obesity can be defined as excess body fat, which increases the risk of different diseases. It is progressing in a quasi-epidemic mode in industrialized countries, and is constantly appearing and spreading in developing countries, [1]. It is widespread worldwide [2], both among men and women, across all age groups and across all ethnicities. In Morocco, more than 10 million adults suffer from it, of which $63.1 \%$ of women are obese or pre-obese and this number has almost doubled in a decade [3]. The risk of overweight or obesity can be associated either with a family history of obesity, or with a poor diet and an energy imbalance, accentuated by a sedentary lifestyle. The energy imbalance is caused by changes in eating habits, with 
overconsumption of high-calorie foods with a too high glycemic index, rich in carbohydrates and fats and poor in minerals and vitamins between meals (Snacking) [4].

It is a real epidemic [5] which has many consequences for health. It is a risk factor for several diseases, such as cardiovascular disease, type 2 diabetes and cancer [6]. It is also a predisposing factor for other cardio-metabolic health problems, such as insulin resistance and atherogenic dyslipidemia [7]. Overweight and obesity are the leading risk factors for death worldwide. About 3.4 million adults die from it each year. They are linked to more deaths than underweight [8].

Young people today are increasingly aware of the health risks of obesity. This is why the perception of the body image begins to change. The roundness is no longer appreciated as before and it has given way to thinness. To be good in your body, you have to be slim. This idea will gradually be associated with that of "being fit". Indeed, the fear of getting fat becomes omnipresent in the words of young people. Weight has also become an obsession for all young people [9].

Generally, dissatisfaction with negative body image is the result of a negative assessment of physical appearance [10]. Currently, this preoccupation with body image is part of the woman's life and becomes really preoccupying. [11] It is strongly linked to a desire to lose weight and is associated with restrictive dieting and dieting behaviors, as well as regular weight checks [12]. Body dissatisfaction rates vary by gender. They range from $11 \%$ to $72 \%$ in adult women and $8 \%$ to $61 \%$ in men [13]. Fiske and colleagues have also shown that women report more body dissatisfaction than men. It also appears that this dissatisfaction varies among women according to BMI and that women who are overweight or obese would be more dissatisfied with their body, compared to women with normal BMI [13], [14].

Faced with the obesity epidemic, which is a major public health problem worldwide, the WHO asked each country in 2003 [5] to create programs to prevent and management obesity. Information campaigns also carried out by the medical world and the authorities have succeeded in raising consumers' awareness of the dangers of an unbalanced diet.

Prevention begins with nutrition education, with the aim of eating a rationally balanced diet, adopting a healthy eating behavior and engaging in physical activity to prevent a sedentary lifestyle. Generally, however, the first phase of obesity management is a reduction in body weight. In order to balance energy intake, dieting is prescribed for obese subjects, with a change in eating habits: a reduction in the consumption of fatty foods, consumption of foods with low calorie intake (Light foods) and increased consumption of vegetables and fruits. The rise of BP goes simultaneously with the awareness of subjects against obesity.

These products were first designed for people with diabetes and to prevent cardiovascular disease. It was only later that the aesthetic reasons appeared [15].

The consumption of diet products and in particular LP is currently regular for many countries. For the past fifty years, Light foods and preparations have been constantly diversifying and increasing. These products are becoming more and more successful. They are an integral part of our food landscape. They have achieved a high level of penetration towards their consumers, some of whom consume those most often to follow a diet while others do so for aesthetic or health reasons. These products are present in most food categories: sauces, cold cuts, confectionery, drinks, etc. They have gradually become established, because they meet the concerns of current consumers, who want to be slim and fit, everything remaining greedy. Generally, the consumption of these products was rather feminine and seasonal at the beginning, but thereafter, it became widespread and it is now regular [16]. LP is food products whose energy density has been reduced, by lowering their content of some nutrients (generally lipids and / or sugars). This reduction in calories can be either a third or a half [17] and often by replacing those with ingredients that seek to restore the flavor and texture of the familiar food. There are also products low in salt, cholesterol, or alcohol, which address other types of concerns, and represent a much smaller market. However, a light food is not necessarily good for health. The opinions on this type of food are too controversial. True, they have a low energy intake, but they can lead to cognitive restriction, by worsening eating disorders. [15] On the other hand, these products can present a risk and a danger for the health of the consumer. Some studies have shown that they are as caloric as non-light products and that, because of their "chemical" nature; additives are harmful to health [18].

According to some studies focused on obesity, nutritional claims have harmful effects on the health of individuals, especially with the significant increase in the amounts consumed when the product is displayed as reduced [19], [20]. The risk of these ingested foods is reflected in the appearance of their side effects [21] which can result in weight loss or gain.

Sweeteners are widely used in the manufacture of several light products. These false sugars have either a chemical (saccharin, aspartame (synthetic sweetener)) or vegetable origin. Saccharin and aspartame provide no calories. Several studies have shown that the consumption of some components added to light products and especially aspartame presents a great risk, especially among daily consumers of many sodas containing it. It is present in the majority of light products and is likely to cause many side effects on health. Thus, the use of this sweetener is questionable and controversial [22]. 
Polyols (sorbitol, xylitol, and mannitol) are used in "sugar-free" candies or chewing gum. Their consumption in high doses can lead to intestinal disorders. They are caloric and their use must be reasoned in the obese population and type 2 diabetic [23]. Rébaudioside A (Stevia) and sucralose (Splenda) are also used and have a natural origin. Pouyat, showed in 2018 [24] that sucralose alters glucose metabolism and decreases sensitivity to insulin. Stevia has been placed on the Moroccan market in recent years. Its health effects are still unclear.

Several studies have shown the effects of AP on the health of consumers, but the impact of these products on the prevalence of obesity remains poorly documented in Morocco, it is in this context that this work was carried out and which for the purposes of studying through a survey:

- AP consumption by students (frequency, reason, duration of consumption and type).

-Effects of consuming these products on the prevalence of obesity

\section{2- METHODOLOGY}

This is a descriptive cross-sectional study, carried out in 2017, on a population of 300 students from different fields at the Ben M'Sik Faculty of Sciences, including $54 \%$ girls and $46 \%$ boys and whose age ranged from 18 to 29 years old. This faculty is a higher education and research establishment, which is attached to the Hassan II University of Casablanca (MOROCCO). The latter brings together six university establishments. The Ben M'Sik Faculty of Sciences welcomed the academic year 2016-2017, 11,500 students, coming from the prefectures of Ben M'Sik, Moulay Rchid-Sidi Othmane, Sidi Bernoussi, Ain Sebâa-Hay Mohammadi and Mohammedia. .

\subsection{Survey}

The study was carried out by means of a questionnaire which included several sections:

- The first is related to overall physical self-satisfaction, which was determined by the SPG Questionnaire by Marsh and colleagues [25] adapted to Moroccan culture. The respondent was supposed to answer each of the 4 questions related to the satisfaction of the physique, the physical appearance and if the person felt well physically, by checking one of the 4 proposals (1Not at all, 2-A little , 3-Enough, 4-Absolutely).

- The second related to the consumption of AP (reasons, duration, attitude, types of products (Dairy products, butters (margarines), sweet products (cookies and cereals, jams, etc.), cold cuts, ready-to-eat dishes, etc...).

- The third related to anthropometric measurements as well as the effect of this consumption on the prevalence of obesity. Several anthropometric parameters were studied (weight, height, waist circumference, hip circumference, TT / TH ratio and BMI). The size of the respondents was determined using a collapsible height rod (Seca), while standing, while the weight (Kg) was measured using an impedance scale (OMRON BF511). The measurement of the waist $(\mathrm{cm})$ and hip measurement was made with a measuring tape, in the standing position. Waist measurement is measured from the narrowest part of the trunk, usually above the navel. It quantifies abdominal obesity in a simple way. Waist circumference is considered to be increased when it is greater than $88 \mathrm{~cm}$ in women and $102 \mathrm{~cm}$ in men. The hip measurement is the horizontal circumference of the body, measured at the strongest point below the waist.

The waist-to-hip ratio (RTH) is used to estimate the android or gynoid fat distribution. Android obesity is reported for an RTH of more than 1 in men and more than 0.85 in women. The body mass index (BMI) was calculated from the subject's weight and height.

$\mathrm{BMI}=$ Weight $(\mathrm{Kg}) /$ height $^{2}\left(\mathrm{~m}^{2}\right)$ BMI is used to assess the risk of illnesses linked to excess or underweight. In adults, BMI is used to classify subjects according to their nutritional status, using the standards of the World Health Organization [26] (WHO, 2000). According to this classification, BMI $<18.5$ reflects a leanness, the "normal" BMI is between $18.5 \mathrm{~kg} / \mathrm{m}^{2}$ and $24.9 \mathrm{Kg} /$ $\mathrm{m}^{2}$. A BMI between $25 \mathrm{Kg} / \mathrm{m}^{2}$ and $29.9 \mathrm{Kg} / \mathrm{m}^{2}$ corresponds to overweight and above $30 \mathrm{Kg} / \mathrm{m}^{2}$, we talk about obesity. Between 30 and 35: Moderate obesity, between 35 and 40: Severe obesity, beyond 40, it is massive obesity. A pre-test was carried out to test the questionnaire, after which some questions were modified and the final version was developed. The final version of the questionnaire was administered by the investigators to the student volunteers, after signing an informed consent and obtaining information about the objectives of the study.

2.2. Ethical considerations: The study was carried out in accordance with the Helsinki declarations on experimentation and medical research on living beings. The basic principles are as follows: voluntary participation, right of the interviewee to renounce their participation at any time, respect for the integrity of the person and their private life, confidentiality of data, freedom not to respond to some questions.

2.3. Statistical analysis of the results: Data were entered and coded in Excel. The statistical analysis was carried out using the SPSS software (Statistical Package for Social Sciences), version 21. This software allows the calculation of the significance, the means as well as the standard deviations. The quantitative variables were expressed in means and standard deviations, while the 
qualitative variables in numbers and in percentages. Pearson's Chi-square test allowed comparison between the qualitative variables. The value $\mathrm{p}<0.05$ is considered to be statistically significant.

\section{RESULTS}

In our student population, the average age is 22 years \pm 2.067 . The extreme ages are 18 and 29 years old. The most frequent age group among our respondents is between 18 and 23 years (86\%); 10\% are between 24 and 26 years old and $4 \%$ between 27 and 29 years old. $65 \%$ of students follow their studies in $2^{\text {nd }}$ and $3^{\text {rd }}$ year, $19 \%$ in $1^{\text {st }}$ year of License, $11.7 \%$ in master and 4.3 in Doctorate.

\subsection{Consumption of Light products (LP)}

\subsubsection{Frequency of consumption}

We note that $19.9 \%$ of respondents never consume LP, $59.2 \%$ consume it sometimes, $18.6 \%$ daily. This consumption varies according to gender. Girls consume more BP $(48.7 \%)$ than boys $(29.1 \%)(p=0.04)$. It also varies according to age. Thus, $71.1 \%$ consuming these products are between 17 and 25 years of age, with greater consumption among the youngest (36.5\%) (Table 1).

Table 1: Distribution of the consumption of light products (never, sometimes, daily) according to the age groups of the students surveyed (17-19, 20-22, 23-25, 26-28 years)

\begin{tabular}{|c|c|c|c|c|}
\hline \multirow{2}{*}{ Consumption } & \multicolumn{3}{|c|}{ Age of students (years) } \\
\cline { 2 - 5 } & $17-19$ & $20-22$ & $23-25$ & $26-28$ \\
\hline Never & $5,6 \%$ & $9,3 \%$ & $3,7 \%$ & $1,3 \%$ \\
\hline Sometimes & $28,8 \%$ & $18,8 \%$ & $6,7 \%$ & $4,7 \%$ \\
\hline Daily & $7,5 \%$ & $5,7 \%$ & $3,5 \%$ & $1,9 \%$ \\
\hline Can't answer & $1,1 \%$ & $0,5 \%$ & $0,7 \%$ & $0 \%$ \\
\hline
\end{tabular}

\subsubsection{Most consumed types of light products}

- The light products marketed in Morocco are quite diverse. The choices of light products vary according to the respondents. Thus, $20.9 \%$ buy light dairy products, $17.7 \%$ a little of all the LP sold, $4.5 \%$ butters (margarines) and $10.5 \%$ some sweet products (cookies and cereals, jams, etc.). This motivation to buy some products varies according to gender (15.2\% of girls consume lowlight products, against $7.5 \%$ of boys; $9.7 \%$ of girls consume a little of all the products sold against $8 \%$ boys...) (Figure 1 ).

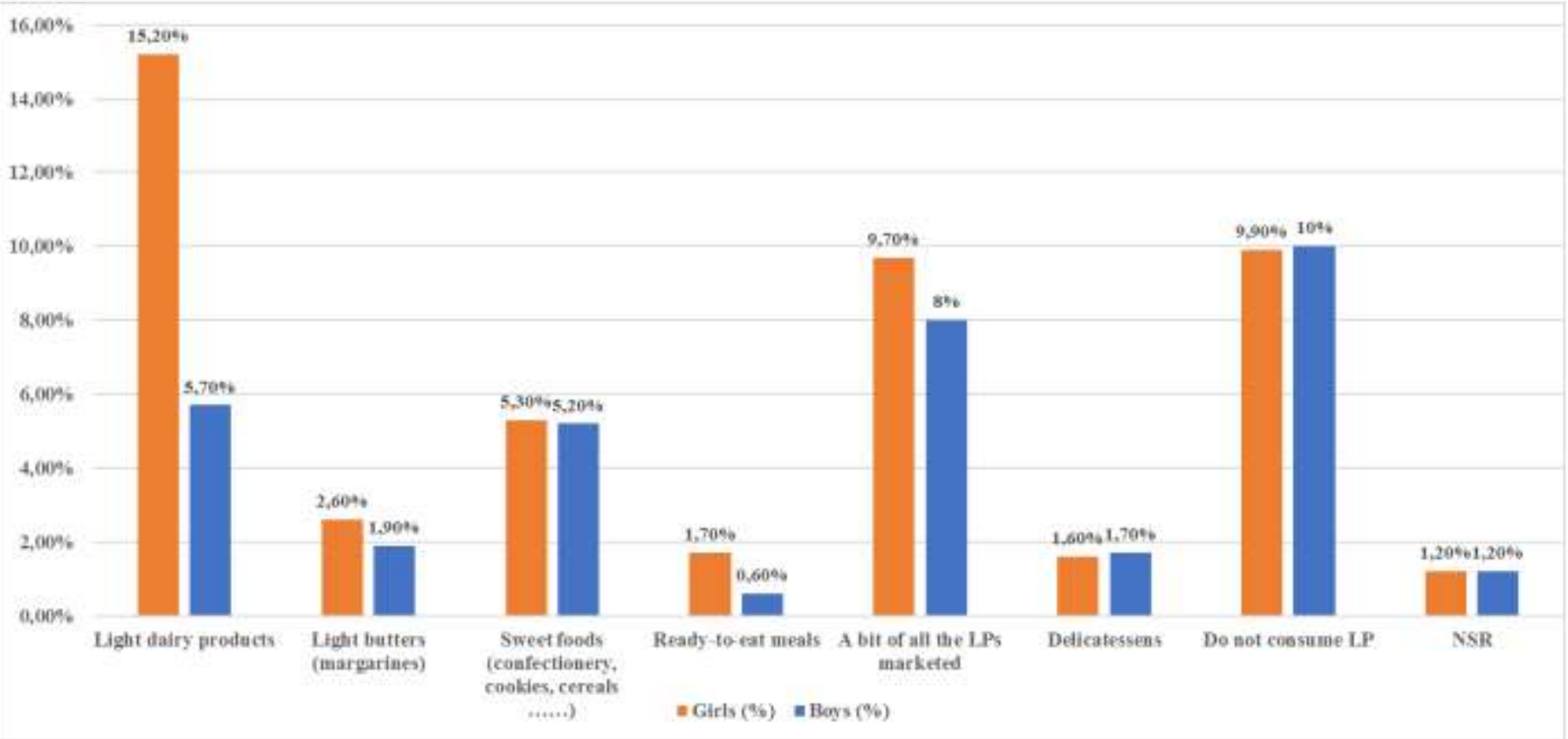

Fgure 1: Distribution of consumers according to the most purchased Light products (light dairy products, butters, sweet foods, ready-to-eat meals, a little bit of all the light products cold meats) and by gender (boys, girls) 
- $47.5 \%$ of those surveyed consume LPs in sugar (of which $31 \%$ are girls and $16.5 \%$ are boys) and $30.3 \%$ are reduced in fat content (of which $20.3 \%$ are girls and $10 \%$ are boys), with a statistically significant difference between the two gender ( $p=0.019$; Khi2 = 7.878).

- The fat LPs most consumed by participants are dairy products (48.7\%) (Yogurts, Cottage cheese and 0\% fat milk). It also appears from this study that girls consume more dairy products than boys, respectively $30.7 \%$ and $18 \%$ ( $\mathrm{p}=0.000$; Khi $2=$ 33.699). Light chips are also fairly consumed by students (16.4\%). The same is true for light butter or margarine (10\%) (Figure 2).

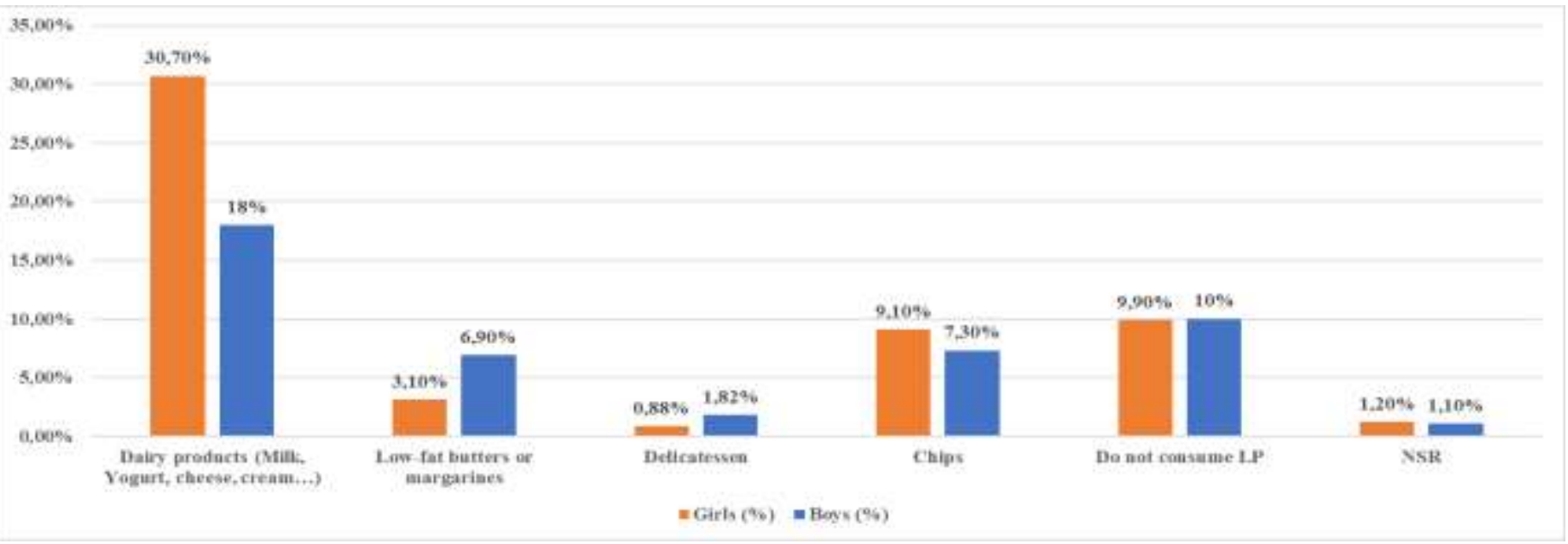

Figure 2: Distribution of respondents according to the type of light product consumed (dairy products, butters, cold meats, crisps) and by gender (boys, girls)

- The sugar LPs most consumed by the population in decreasing order are confectionery (candies, chocolates, chewing-gum, etc.) (32.3\%), light drinks (23\%); jams, dairy desserts, cereals, cookies ... (12.8\%) and 0\% yogurt (12\%). Our results also showed that the type of light product consumed varies according to gender, with a statistically significant difference between the two gender ( $\mathrm{p}$ $=0.019 ;$ Khi2 = 7.878) (Figure 3).

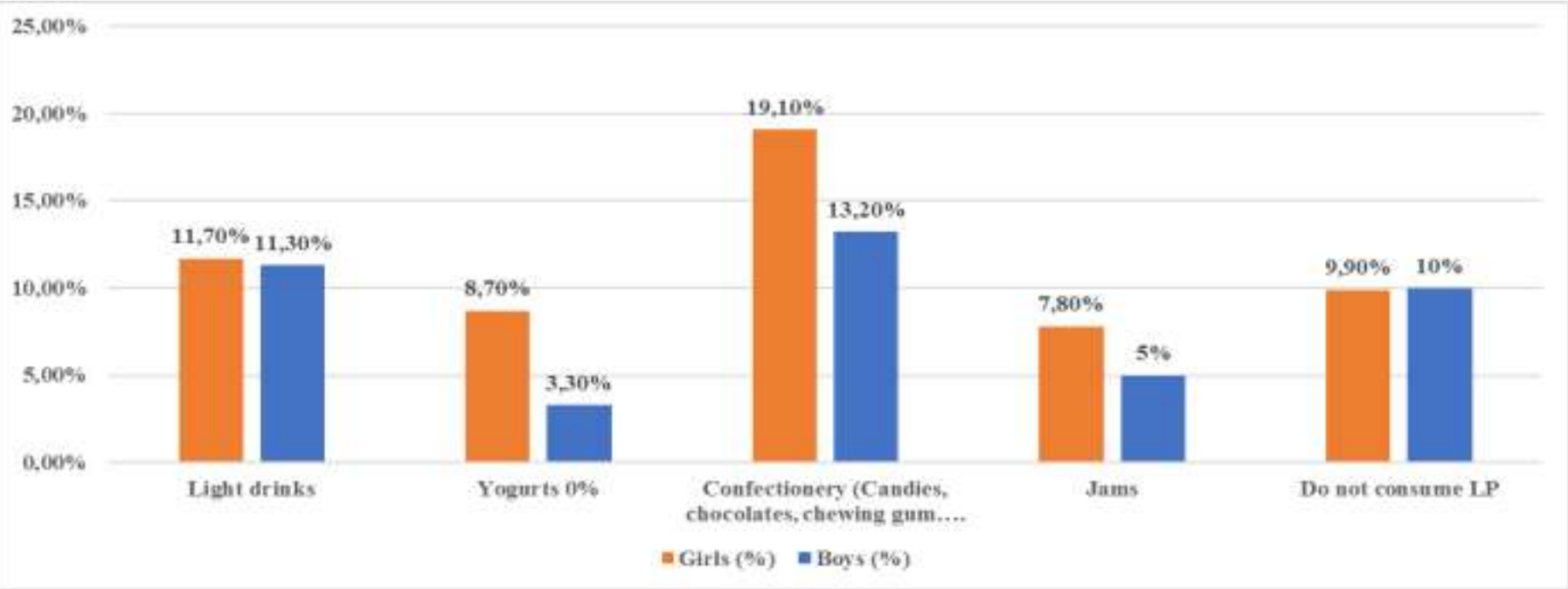

Figure 3: Distribution of students according to the type of low-sugar product consumed (drinks, yogurts, confectionery, jams, etc.) and by Gender (girls, boys)

\subsubsection{Reasons and period of consumption of light products (LP):}

- $28.9 \%$ of students consume them to lose weight, $27.3 \%$ think they are best for good health, $12 \%$ like their good taste and $6.8 \%$ for being able to cope with differences in other foods. This reason for consumption varies according to gender. $18.9 \%$ of girls compared to $10 \%$ of boys consume them to lose weight; while $18.5 \%$ of girls compared to $8.8 \%$ of boys think they are better for their health $(\mathrm{p}<0.05)$ (Table 2). 
International Journal of Advances in Scientific Research and Engineering (ijasre), Vol 6 (3), March -2020

Table 2: Distribution of respondents according to the reasons for consuming LP (to lose weight, because they are better for health, to be able to cope with differences in other foods, because they taste good) and according to gender (Masculine or feminine)

\begin{tabular}{|l|l|l|l|}
\hline \multicolumn{1}{|c|}{ Reasons for consumption } & Total (\%) & Girls (\%) & Boys (\%) \\
\hline To slim down & $28,9 \%$ & $18,9 \%$ & $10 \%$ \\
\hline They are better for health & $27,3 \%$ & $18,5 \%$ & $8,8 \%$ \\
\hline To be able to cope with deviations on other foods & $6,8 \%$ & $2,95 \%$ & $3,85 \%$ \\
\hline They taste good & $12 \%$ & $9,79 \%$ & $2,21 \%$ \\
\hline Can't answer & $5,1 \%$ & $2,2 \%$ & $3,31 \%$ \\
\hline Do not consume PA & $19,9 \%$ & $9,9 \%$ & $10 \%$ \\
\hline
\end{tabular}

- Regarding the period of consumption of LP, generally, students consume it when they are on a diet. Half of the students do not practice a diet $(50.1 \%)$. For those who make it, $12.6 \%$ include only a few Light products in their meals while $19.2 \%$ do not change their eating habits, but only pay attention to the amounts of food consumed. On the other hand, $15.8 \%$ systematically bet on light products (Table 3).

Systematic use of AP when students are on a diet varies according to gender $(11.1 \%$ for girls and $4.7 \%$ for boys, with a statistically significant difference between the two gender $(\mathrm{p}<0.05)$.

Table 3: Distribution of students according to the consumption of Light products and according to diet practice (consumer is not on a diet, consumer on a diet (he only includes a few Light products in his meals, He does not change his habits but does only pay attention to the quantities of food consumed, He systematically focuse on Light products)

\begin{tabular}{|c|c|c|}
\hline \multicolumn{2}{|c|}{ LP consumption and diet practice } & Percentage $(\%)$ \\
\hline \multicolumn{2}{|l|}{ The consumer is not on a diet } & $50,1 \%$ \\
\hline \multirow{3}{*}{$\begin{array}{l}\text { The consumer practices the } \\
\text { diet }\end{array}$} & He only incorporates a few Light products into his meals & $12,6 \%$ \\
\hline & $\begin{array}{l}\text { He does not change his habits but only pays attention to the } \\
\text { quantities of food consumed }\end{array}$ & $19,2 \%$ \\
\hline & It systematically focuses on light products & $15,8 \%$ \\
\hline \multicolumn{2}{|l|}{ Can't answer } & $2,3 \%$ \\
\hline
\end{tabular}

\subsubsection{Duration of consumption of light products.}

$23.2 \%$ of students have consumed it for 6 months, $22.3 \%$ for a year, $14.2 \%$ for 2 years, $4.2 \%$ for 5 years, $11.1 \%$ for more than 5 years. This duration varies according to gender ( $8.9 \%$ of girls and $4.9 \%$ of boys consume them for 6 months; $6.5 \%$ of girls and $5.8 \%$ of boys consume light products for a year) (figure 4). This consumption duration is not statistically significant ( $\mathrm{p}=0.264$; Khi2 = 3.981). 
International Journal of Advances in Scientific Research and Engineering (ijasre), Vol 6 (3), March -2020

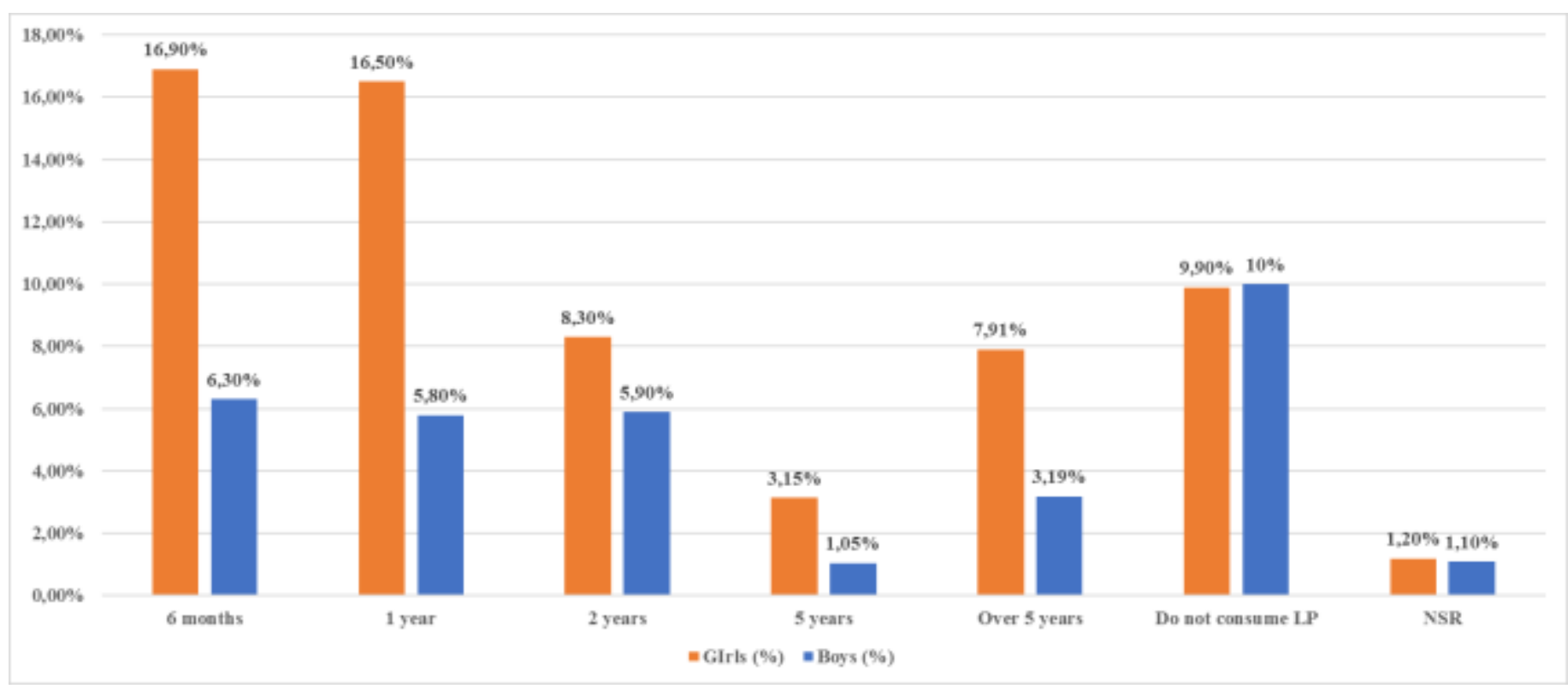

Figure 4: Distribution of students surveyed according to the duration of consumption of LP 6 months, 1 year, 2 years, 5 years, more than 5 years) and by gender (boys, girls)

\subsection{Reduced product prices.}

$31.3 \%$ of the population studied think that the prices of light products are a little high compared to conventional products, while $21 \%$ declare that these products are not worth this price difference, $22 \%$ think that they are very expensive, $18 \%$ think they are expensive because they are fashionable and $7.7 \%$ cannot answer (Table 4).

Table 4: Distribution of students according to their opinion on the price of LP (High price of LP compared to the rest of the classic products, LP are not worth this price difference, LP are very expensive, they are expensive because they are fashionable)

\begin{tabular}{|l|l|}
\hline Students' opinions on LP prices & Percentage (\%) \\
\hline High price of LP compared to the rest of conventional products & $31,3 \%$ \\
\hline LPs are not worth this price difference & $21 \%$ \\
\hline LPs are very expensive & $22 \%$ \\
\hline They are expensive because they are fashionable & $18 \%$ \\
\hline Can't answer & $7,7 \%$ \\
\hline
\end{tabular}

3.3. Channels influencing the acts of purchasing a light product:

It appears from this study that the media are the powerful vehicles to trigger the purchase of Light products. Thus, $34.4 \%$ of students buy the product following an advertisement, $28.4 \%$ because it was recommended to them by a friend, $18.5 \%$ because of its good composition, $16.2 \%$ because of the packaging and $2.5 \%$ for other reasons (Table 5 ).

Table 5: Distribution of respondents according to the channels influencing the acts of purchasing a light product (media (advertising, because of the good composition, it was recommended by a friend, because of the packaging (packaging), for other reasons)

\begin{tabular}{|l|l|}
\hline Channels influencing the acts of purchasing a LP & Percentage (\%) \\
\hline Media (advertising) & $34,4 \%$ \\
\hline Because of the good composition & $18,5 \%$ \\
\hline
\end{tabular}


International Journal of Advances in Scientific Research and Engineering (ijasre), Vol 6 (3), March -2020

\begin{tabular}{|l|l|}
\hline It was recommended by a friend & $28,4 \%$ \\
\hline Because of the packaging & $16,2 \%$ \\
\hline For other reasons & $2,5 \%$ \\
\hline
\end{tabular}

\subsection{Anthropometric parameters.}

- The average anthropometric parameters of the population are shown in Table 6.

Table 6: Average anthropometric parameters of respondents (weight, height, waist measurement, hip measurement, TH ratio, body mass index)

\begin{tabular}{|l|c|}
\hline Average anthropometric parameters & Averages \pm Standard deviation (SD) \\
\hline Weight $(\mathrm{kg})$ & $68,35 \pm 12,18 \mathrm{Kg}$ \\
\hline Height $(\mathrm{cm})$ & $167,54 \pm 9,43 \mathrm{~cm}$ \\
\hline Waist measurement $(\mathrm{cm})$ & $78,93 \pm 9,48 \mathrm{~cm}$ \\
\hline Hip measurement $(\mathrm{cm})$ & $98,30 \pm 7,22 \mathrm{~cm}$ \\
\hline TH report & $0,79 \pm 0,06$ \\
\hline BMI $(\mathrm{Kg} / \mathrm{m} 2)$ & $24,58 \pm 3,39$ \\
\hline
\end{tabular}

$61.66 \%$ of the population have a normal BMI (between 18 and $25 \mathrm{~kg} / \mathrm{m}^{2}$ ), 29.66\% are overweight (BMI between 25 and $30 \mathrm{~kg} /$ $\mathrm{m}^{2}$ ) of which $11.76 \%$ are boys and $17,9 \%$ are girls and 4.45 moderate obesity (BMI between 30 and $34 \mathrm{~kg} / \mathrm{m}^{2}$ ), of which $1.2 \%$ are boys and $3.25 \%$ are girls. It was also observed that $4.23 \%$ of the students were thin and who were all girls with a significant difference between the two gender $(\mathrm{p}<0.05)$ (Figure 5)

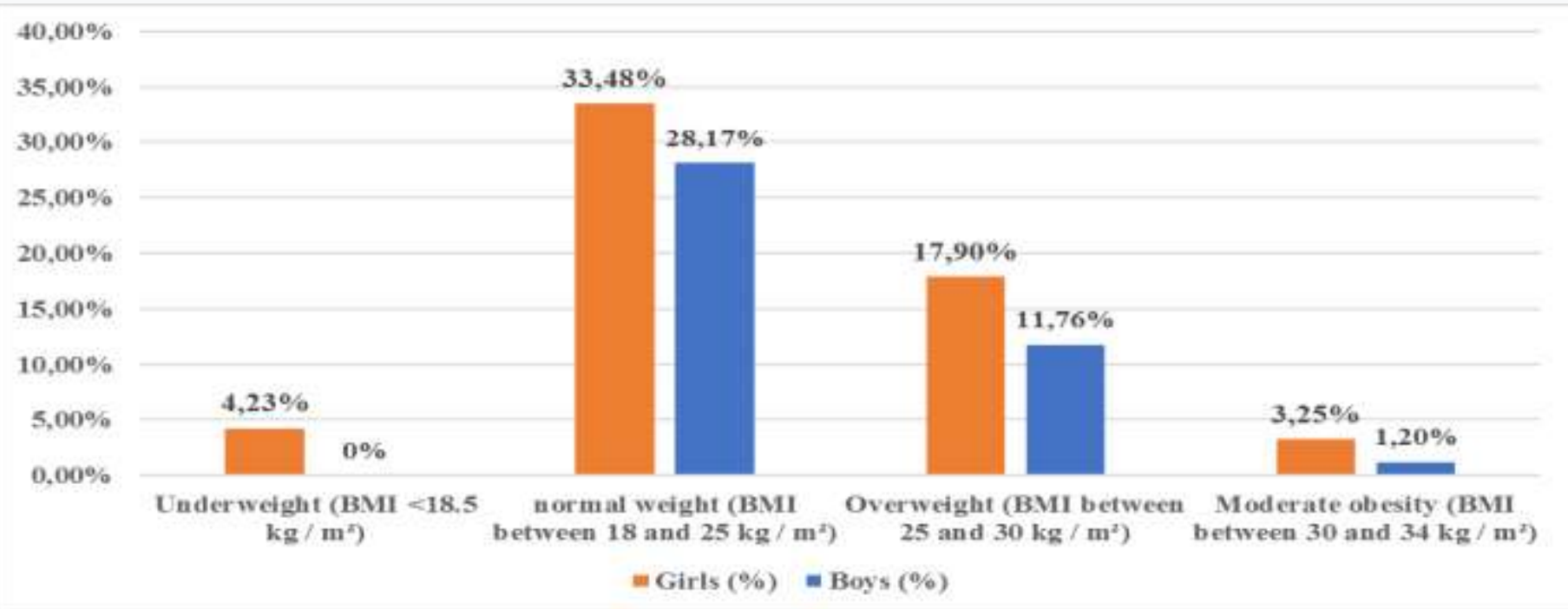

Figure 5: Distribution of respondents according to the body mass index (BMI) (leanness, normal build, overweight, moderate obesity) and by gender (boys, girls)

3.5. Perception of body image by students:

- $34 \%$ of those surveyed are completely satisfied with their body image, $44 \%$ feel that they are quite satisfied, $14 \%$ somewhat and $8 \%$ are not at all satisfied. A slight statistically significant difference was observed between satisfaction with body image and gender $(\mathrm{p}=0.048$; Khi $2=0.287$ ) (Figure 6). This level of satisfaction appears to be associated with BMI $(\mathrm{p}=0.012 ;$ Khi2 $=$ 285.19). 
International Journal of Advances in Scientific Research and Engineering (ijasre), Vol 6 (3), March -2020

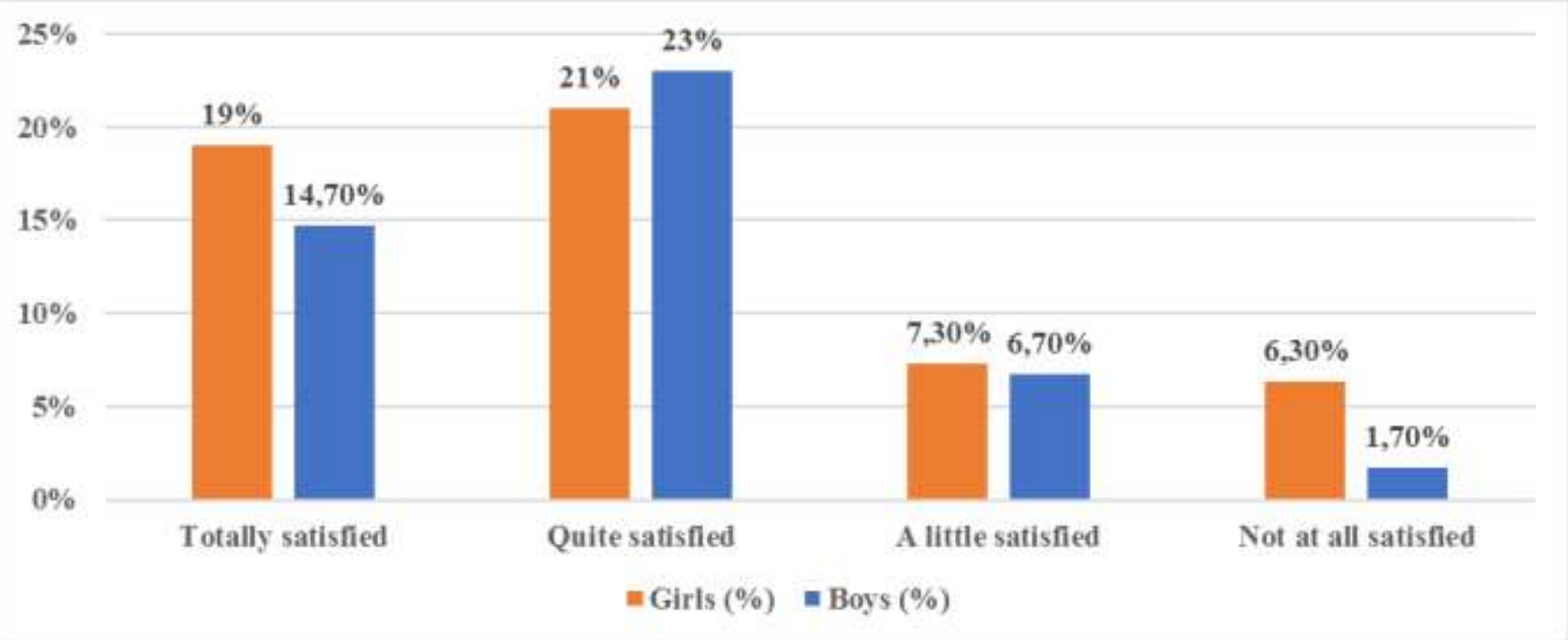

Figure 6: Satisfaction level of the body in function (totally satisfied, somewhat satisfied, somewhat satisfied, not at all satisfied) of gender (boys, girls)

3. 6. Study of the correlations between the different parameters:

3.6.1 - BMI according to the frequency of consumption of LP

$47.05 \%$ of consumers of light products have a normal weight (43.77\% consume them sometimes and $3.28 \%$ daily), $24.16 \%$ are overweight, including $12.3 \%$ sometimes and $11.86 \%$ daily and $3,86 \%$ moderate obesity including $1.16 \%$ sometimes and $2.7 \%$ daily. It should also be noted that $2.73 \%$ of consumers of these products are underweight. On the other hand, $1.5 \%$ of those who do not consume these products are thin, $12.3 \%$ have normal build, $5.5 \%$ are overweight and $0.6 \%$ have moderate obesity $(\mathrm{p}=$ 0.043; Khi2 = 87.43) (Table 7).

Table 7: Distribution of respondents according to the consumption of light products (do not consume them, sometimes consume them, daily consumption) and according to BMI (leanness, normal build, overweight, moderate obesity)

\begin{tabular}{|c|c|c|c|c|c|}
\hline LP consumption & $\begin{array}{c}\text { thinness } \\
(\mathrm{BMI}<18.5 \\
\left.\mathrm{Kg} / \mathrm{m}^{2}\right)\end{array}$ & $\begin{array}{c}\text { Normal (BMI } \\
\text { between } 18-24.9 \\
\left.\mathrm{Kg} / \mathrm{m}^{2}\right)\end{array}$ & $\begin{array}{c}\text { overweight } \\
\text { (BMI between } \\
\left.25-29.9 \mathrm{Kg} / \mathrm{m}^{2}\right)\end{array}$ & $\begin{array}{c}\text { Moderate obesity } \\
\text { (BMI between } 30 \\
\text { and } 34 \mathrm{Kg} / \mathrm{m}^{2} \text { ) }\end{array}$ & significance \\
\hline Never consume LP & 1,5 & $12,3 \%$ & $5,5 \%$ & $0,6 \%$ & \multirow{4}{*}{$\begin{array}{l}\mathrm{p}=0,043 ; \\
\text { Khi } 2=87,43\end{array}$} \\
\hline Sometimes consumption & $2 \%$ & $43,77 \%$ & $12,3 \%$ & $1,16 \%$ & \\
\hline Daily consumption & 0,73 & $3,28 \%$ & $11,86 \%$ & $2,70 \%$ & \\
\hline Can't answer & 0 & $2,3 \%$ & 0 & 0 & \\
\hline \multicolumn{6}{|c|}{ Type of AP } \\
\hline LP in sugar & $1,2 \%$ & $25,3 \%$ & $16,6 \%$ & $2,3 \%$ & \multirow[t]{2}{*}{$\begin{array}{l}\mathrm{p}=0,359 ; \\
\text { Khi } 2=81,92\end{array}$} \\
\hline LP fatty acid & $1,53 \%$ & $22,76 \%$ & $6,56 \%$ & $2,15 \%$ & \\
\hline \multicolumn{6}{|c|}{ LP consumption time } \\
\hline 6 months & $0,5 \%$ & $10,8 \%$ & $2,46 \%$ & $0,24 \%$ & \multirow{4}{*}{$\begin{array}{l}\mathrm{p}=0,000 \\
\text { Khi } 2=348,91\end{array}$} \\
\hline 1 Year & $0,45 \%$ & $8,57 \%$ & $2,8 \%$ & $0,48 \%$ & \\
\hline 2 Years & $0,45 \%$ & $8,1 \%$ & $4,05 \%$ & $0,68 \%$ & \\
\hline 5 Years & $0,5 \%$ & $2,1 \%$ & $2,3 \%$ & $0,30 \%$ & \\
\hline
\end{tabular}


International Journal of Advances in Scientific Research and Engineering (ijasre), Vol 6 (3), March -2020

\begin{tabular}{|l|l|l|l|l|l|}
\hline Over 5 years & $0,83 \%$ & $4,66 \%$ & $5,4 \%$ & $0,23 \%$ & \\
\hline
\end{tabular}

\subsection{2-BMI depending on the type of light food consumed:}

For consumers of fatty acid LPs, $6.56 \%$ are overweight and $2.15 \%$ moderate obesity, while for consumers of products low in sugar, $16.6 \%$ are overweight and $2.3 \%$ are moderately obese. On the other hand, for non-consumers of LP, $1.5 \%$ is lean, $12.3 \%$ have a normal build, $5.5 \%$ are overweight and $0.6 \%$ is obese (Table 7).

The difference between BMI and the type of light food is not statistically significant $(\mathrm{p}=0.359$; Khi2 $=81.92$ )

2.6.3-BMI according to the duration of consumption of LP:

Our results show that the duration of consumption of LP influences the prevalence of obesity. Thus, the frequency of overweight increases especially between 2 years $(4.05 \%)$ and more than 5 years $(5.4 \%)$. A statistically significant association was observed between BMI and the duration of consumption of light foods $(\mathrm{p}=0.000$; Khi2 $=348.91)$ (Table 7$)$

\subsection{4-BMI and diet practice}

For students who are not dieting, $34.9 \%$ are normal, $11.54 \%$ are overweight and $1 \%$ moderate obesity. For those who are on a diet and who do not consume AP, just under half have normal build (13.3\%), a quarter overweight (4.32\%) and $1.1 \%$ obesity. Whereas for those who bet systematically on the light, half are overweight $(7.7 \%)$ and $1.78 \%$ are obese. Half of those who integrate some light products $(5.7 \%)$ are overweight and $1.7 \%$ is obese. No statistically significant association was observed between BMI and diet practice $(\mathrm{p}=0.052 ; \mathrm{Khi} 2=230.20)$.

Table 8: Distribution of the consumption of light products according to the practice or not of the diet (does not diet, he is on a diet (he systematically uses light, he integrates some LP into his meals, he does not change anything of his habits but he pays attention to the quantities)) and according to the BMI (thinness, normal build, overweight, moderate obesity).

\begin{tabular}{|c|c|c|c|c|c|}
\hline & $\begin{array}{l}\text { Thinness } \\
(\mathrm{BMI}<18.5 \\
\left.\mathrm{Kg} / \mathrm{m}^{2}\right)\end{array}$ & $\begin{array}{l}\text { Normal (BMI } \\
\text { between 18-24.9 } \\
\left.\mathrm{Kg} / \mathrm{m}^{2}\right)\end{array}$ & $\begin{array}{l}\text { overweight } \\
\text { (BMI between 25- } \\
\left.29.9 \mathrm{Kg} / \mathrm{m}^{2}\right)\end{array}$ & $\begin{array}{l}\text { Moderate obesity } \\
\text { (BMI between } 30 \\
\text { and } 34 \mathrm{Kg} / \mathrm{m}^{2} \text { ) }\end{array}$ & significance \\
\hline I systematically put on the light & $0,7 \%$ & $6,1 \%$ & $7,7 \%$ & $1,78 \%$ & \multirow{5}{*}{$\begin{array}{l}\mathrm{p}=0,052 \\
\text { Khi2 }=230,20\end{array}$} \\
\hline I include some LP in my meals & $0,4 \%$ & $5,86 \%$ & $5,7 \%$ & $1,7 \%$ & \\
\hline $\begin{array}{l}\text { I don't change anything about } \\
\text { my habits, but I pay attention to } \\
\text { the quantities }\end{array}$ & $0,5 \%$ & $13,3 \%$ & $4,32 \%$ & $0,11 \%$ & \\
\hline I'm not dieting & $2,03 \%$ & $34,9 \%$ & $11,54 \%$ & $1 \%$ & \\
\hline Can't answer & $0,6 \%$ & $1,3 \%$ & $0,4 \%$ & $0 \%$ & \\
\hline
\end{tabular}

\subsection{6- BMI according to the satisfaction of the body image:}

It appears that those who are not at all satisfied with their body image are more overweight $(9.11 \%)$ and obese $(1.66 \%)$. On the other hand, those who are completely satisfied have the least overweight $(3.3 \%)$ and obesity $(0.61 \%)$. A statistically significant association was observed between BMI and satisfaction with body image $(\mathrm{p}=0.012$; Chi-square $=285.19)$. 
International Journal of Advances in Scientific Research and Engineering (ijasre), Vol 6 (3), March -2020

Table 9: Satisfaction with participants' body image (completely satisfied, somewhat satisfied, somewhat satisfied, not at all satisfied) according to lean BMI, normal build, overweight, moderate obesity)

\begin{tabular}{|c|c|c|c|c|c|}
\hline & $\begin{array}{l}\text { thinness } \\
(\mathrm{BMI}<18.5 \\
\left.\mathrm{Kg} / \mathrm{m}^{2}\right)\end{array}$ & $\begin{array}{l}\text { Normal (BMI between } \\
\left.18-24.9 \mathrm{Kg} / \mathrm{m}^{2}\right)\end{array}$ & $\begin{array}{l}\text { overweight } \\
\text { (BMI between } 25 \text { - } \\
\left.29.9 \mathrm{Kg} / \mathrm{m}^{2}\right)\end{array}$ & $\begin{array}{l}\text { Moderate obesity } \\
\text { (BMI between } \\
30 \text { and } 34 \mathrm{Kg} / \mathrm{m}^{2} \text { ) }\end{array}$ & significance \\
\hline Totally satisfied & $1 \%$ & $25,4 \%$ & $3,3 \%$ & $0,61 \%$ & \multirow{4}{*}{$\begin{array}{l}\mathrm{p}=0,012 \\
\text { Khi2 }=285,19\end{array}$} \\
\hline Somewhat satisfied & $1,01 \%$ & $24,7 \%$ & $5,36 \%$ & $0,69 \%$ & \\
\hline Not very satisfied & $1,2 \%$ & $6,33 \%$ & $9,11 \%$ & $1,49 \%$ & \\
\hline Not at all satisfied & $0,02 \%$ & $5,23 \%$ & $11,9 \%$ & $1,66 \%$ & \\
\hline
\end{tabular}

\subsubsection{Consumption of some light foods and BMI:}

An association was observed between the consumption of light drinks and BMI ( $\mathrm{p}=0.006$; Khi2 $=287.14)$. On the other hand, no association was observed between the BMI and the consumption of light dairy products $(\mathrm{p}=0.215$; Khi2 = 38.00), cured meats and BMI ( $\mathrm{p}=0.541$; Khi2 $=1.229)$, as well as between crisps and BMI.

\section{DISCUSSION:}

The aim of this work was to study the prevalence of obesity in a population of students of the Ben M'Sik Faculty of Science, whether or not they consume LP, by means of a survey.

We noticed that $34 \%$ of the respondents are completely satisfied with their bodies, $44 \%$ consider themselves to be quite satisfied, $14 \%$ somewhat and $8 \%$ are not at all satisfied, with a significant difference between the two gender ( $\mathrm{p}<0.05$ ). Body dissatisfaction "refers to a negative subjective evaluation of one's own body in terms of weight but also of one's physical appearance [27]. Dissatisfaction with body image will induce body weight control behaviors such as restrictive diets [28]. Shroff and colleagues noted in 2006 [29] that the socio-cultural environment would therefore play an important role in the development of adolescent bodily dissatisfaction.

The dissatisfaction of the body image pushes the subjects to seek solutions for a better wellbeing to avoid the overweight and all the health problems related to obesity. The search for an ideal body has now become a fashion phenomenon and young Moroccans are not immune to this phenomenon. Thus, young people of both genders follow draconian diets, consume light foods and play sports to have the body of their dreams.

Just over half of the students consumed these light products. 59.2\% consumed them sometimes and $18.6 \%$ daily. This consumption varies by gender and by age. Girls are more likely than boys to consume these light products (48.7\%) consume AP more than boys (29.1\%) and $73.7 \%$ consuming these products are between the ages of 17 and 25 years, with higher consumption among the youngest (37.1\%). For the consumer, "light" is often synonymous with "good for health" or "dietetic". This could be explained by some current beauty criteria which push young people to think about preserving their lines.

The choices of products lightened by the respondents vary depending on the products marketed: $20.9 \%$ buy light dairy products, $17.7 \%$ a little of all the AP sold, $4.5 \%$ butters (margarines) and 10.5\% some sweet products (cookies and cereals, etc.). It appears from these results that dairy products are sufficiently consumed by students, although the consumption of these products in Morocco still remains below the standard recommended by the WHO by around 11 points [30]. This is not the case in France where dairy products (classic and reduced in fat and sweetened) have an important place in the French diet: These foods are consumed every week in the form of cheese, milk or yogurt almost the entire population, in both gender and in all age groups [31].

In our population, $47.5 \%$ of those surveyed consume low-sugar products (of which $31 \%$ are girls and $16.5 \%$ are boys) and $30.3 \%$ have low-fat products (of which $23 \%$ are girls and $10 \%$ are boys), with a statistically significant difference between the two sexes ( $\mathrm{p}$ <0.05). Indeed, students are aware of the harmful effects of excessive sugar consumption. This result is different from that of the CREDOC study in 2007 [32], whose authors observed that most regular consumers of low-fat sugars are also regular consumers of low-fat fats. On the other hand, according to this study also, almost half of the doctors expressed reservations about the overconsumption of light sugars because they can present a risk of overweight, sugar dependence and food imbalances. Moreover, the light products are not natural and generally, they have the same organoleptic qualities as the original product (texture, taste, color, consistency and shape), but, these are processed foods, including the effect on health varies according to the degree of processing of food. These are reconstituted foods that are likely to lead to an increase in the prevalence of overweight, obesity and type 2 diabetes, especially among the youngest. They can also deregulate the subject's metabolism, thereby increasing 
the risk of other chronic diseases such as cardiovascular disease and certain digestive cancers [33]. According to these authors, these are fake foods, which can be a cause of death, especially in urban areas [33].

For the channels influencing the acts of purchase of a reduced product among students, this study showed that $24.4 \%$ of students buy the product following an advertisement, $28.4 \%$ because it was recommended by a friend, $18.5 \%$ because of its good composition, and $16.2 \%$ because of the packaging. Indeed, the media (digital or web) (Press, TV, display, etc.) play an increasingly important role in consumer purchasing choices. Advertising is a form of mass communication, the purpose of which is to grab the consumer's attention, in order to encourage them to buy a particular product. In Morocco, digital and radio are the only ones to perform well in recent years. The food market share in 2018 is $7.5 \%$ [34]. The Packaging channel is also important. Marketing slogans always seek to attract people through packaging with the most attractive ads. However, it has been shown that generally, with regard to the choice of light products, several authors have stressed the importance of mental representations in the study of eating behaviors. On the neurological level, this classification method is based on relatively confused and unconscious mechanisms [35].

In our population, $50.1 \%$ of students do not go on a diet. For those who are on a diet, $12.6 \%$ include only a few light products in their meals while $19.2 \%$ do not change anything in their eating habits, but only pay attention to the quantities of food consumed during a diet, so that $15.8 \%$ systematically bet on light products. Students, even if they want to keep a good line, try to eat everything. Besides, you can lose weight by eating everything, provided you choose the right food combinations that respect the mechanisms of digestion [36]. This author also noticed a decrease in the weight of his patients with an improvement in their quality of life. He also noted progress in the more or less long term in the case of several pathologies, such as high blood pressure, diabetes, etc. The reasons for choosing light products vary among consumers. $28.9 \%$ choose them because they are on a diet and want to lose weight, $6.8 \%$ eat them so they can snack without any problems, $27.3 \%$ think they are better for their health and $18 \%$ think they taste good. So most of our respondents believe that this type of food makes them lose weight, but our results have shown that this is not the case, because the consumers of LPs were overweight or obese. In fact, Maillat and Wargnier observed in 2018 [37] that people with reduced weight do not lose weight, unless the diet is supervised by a specialist and when these products are consumed as part of a structured and balanced diet. Other allegations have been made against the accused; the latter are generally produced with the addition of some food additives (sweeteners, fat substitute flavors). Their palatability can lead to overconsumption which can be increased and therefore cause an unwanted effect of this type of product by the consumer.

Thus, Pacini and collaborators noted in 1990 [38] in some subjects an over consumption of the order of 50\% with light spreads, because they are also easier to spread and consumers think that they make "less fat" ". The same result was observed by Simon in 2003 [39] that some individuals consume, without restriction, light products, some of which have high palatability and energy density. $31.3 \%$ of the students surveyed think that the prices of light products are a little high compared to conventional products, while $21 \%$ declare that these products are not worth this price difference and $22 \%$ think that they are very expensive, $18 \%$ think they are expensive because they are fashionable. The prices of these foods are more expensive than conventional products because the price of their manufacture and the advertising costs are more expensive. Different results were observed by Achour in 2012, who carried out a survey at the level of the commune of Sétif in Algeria and who noticed that the opinions of the respondents are divided. Those living in cities with a high level of education believe that improving the quality of a food product increases its cost, which justifies their high price. On the other hand, subjects with a low level of education and living in a rural environment do not perceive the price difference between the conventional product and the light product [40].

Regarding the anthropometric parameters, we noticed that $61.88 \%$ of our population has a normal BMI of which $42 \%$ are girls and $38 \%$ are boys. $29.6 \%$ are overweight with $7.9 \%$ girls and $8.8 \%$ boys and $4.23 \%$ suffer from obesity. We also found that there is a correlation between body image satisfaction and BMI $(\mathrm{p}=0.012$; Khi2 $=285.19)$, and generally people who are satisfied with their bodies have normal BMI. This dissatisfaction also varies according to gender. These results are consistent with those of Fiske et al., in 2014 [13] and those of Tiggemann in 2011 [41], who noted that dissatisfaction among women varied according to BMI and that those with overweight or obesity would be more dissatisfied with their bodies.

Our results also showed that $24.16 \%$ of consumers of the light products were overweight and $3.86 \%$ were moderately obese. This could be related to the ingredients used for the preparation of light foods, but also to the daily food intake. Our results suggest that the duration of LP consumption influences the prevalence of obesity. Thus, the frequency of overweight increases especially between 2 years $(4.05 \%)$ and more than 5 years $(5.4 \%)$.

A statistically significant association was observed between BMI and the duration of consumption of light foods ( $\mathrm{p}=0.000$; Khi2 = 348.91). This result could be explained by the more or less compensatory effect of the energy deficit of light foods in the short and long term. In the short term, the compensation is true in particular with reduced sugar, through the secretion of insulin following the ingestion of foods with a sweet taste. While learning takes place in the long term and in this case, compensation is better [16]. It can therefore be suggested that the consumption of light products is likely to increase weight. Only very few studies 
have scientifically studied the influence of light foods on weight. Lean eating can never make people lose weight unless it is accompanied by good eating habits and regular physical activity. In addition, the consumption of foods with low energy intake, could lead to an energy deficit during the meal, with more or less important compensatory responses to restore the balance of the balance. This energy deficit would cause a feeling of hunger, with an increase in food intake in the hours that follow [16]. Some studies have shown that compensation can take place during subsequent meals. Thus, Louis-Sylvestre and collaborators showed in 1990 [42] during a study carried out on young subjects who have the age comprised between 22-25 years, that the reduction is never compensated during the meal, but compensated at $70 \%$ during the following meals. This compensation also varies depending on the type of relief (in fat or sugar). For foods low in sugar, they usually contain intense sweeteners. These sweeteners are caloric and have a much greater sweetening power than sucrose. Moreover, Blundell and collaborators made in 1988 [43] a record of the food intake of subjects during the hours which follow the mid-morning ingestion, either of a sweetened yogurt (131 Kcal), or of a sweet yogurt $(295 \mathrm{Kcal})$. They observed that the sweetened yogurt was followed by a consumption of $200 \mathrm{Kcal}$ higher than that which followed the yogurt with sucrose. Sucrose and the sweetener will both induce insulin secretion, however, using different mechanisms. Sucrose causes a strong secretion of insulin, by packaging, while the lightened sweetened food will not bring enough calories to the body, insulin will cause hypoglycemia which will be felt by the subject and which will cause a return, early hunger and then stimulation of food intake and therefore energy compensation [42]. Thus, there is a new adjustment to energy needs [44]. Two or three hours after the meal, snacking by hunger can occur and lead to energy compensation. This will therefore result in an increase in energy intake. Thus, these lightened products are likely to cause an eating behavior disorder. This results in a disturbance of the feeling of hunger, satiety, as well as that of pleasure, with excessive consumption. Moreover, several studies have shown that in France, women consuming intense sweeteners had a higher BMI than those who did not consume light products [45]. For the usual consumption of one or more light products, women have a higher BMI and waist and hip measurement than those who never consume it [46]. On the other hand, Slama showed in 1991 in the United States [47] out of 2 populations of women that those who regularly consumed sweeteners and light products for a year, had on average more fattened than those who did not. In contrast, Sarah et al. demonstrated in 2016 [48] that aspartame promotes glucose intolerance and obesity in mice by inhibiting the enzyme alkaline phosphatase. In addition, according to some authors, sweeteners could modify the intestinal microbiota, following the interactions of some intestinal bacteria and with the chemical compounds of sweeteners not absorbed by the intestine. This will promote some inflammatory reactions that cause metabolic disorders, such as diabetes or glucose intolerance [49]. 16.6\% of consumers of LP in sugars are overweight and $2.3 \%$ have obesity. 6.56\% of consumers of reduced fat in GA are overweight and $2.15 \%$ a moderate obesity. In contrast, moderate obesity $(0.6 \%)$ and overweight $(5.5 \%)$ are lower among non-LP users. It therefore appears from these results that LP fatty acids could lead to weight gain. This result agrees with that which was observed by Clarisse and collaborators in 2012 [15]. According to these authors, the over consumption of lipids will help to improve the energy balance.

Currently, scientific studies on the influence of light products on body weight are few. And no study has concluded that these products help control weight in the long term or make you lose weight. It is also extremely difficult to control the exclusive effect of this food category in a diversified diet, because of the large number of factors that can influence body weight. Observational studies which have shown associations between this mode of consumption and the subject's state of health have not been able to provide definite evidence.

We noticed an association between BMI and consumption of light drinks ( $\mathrm{p}=0.006$; Khi2 $=113.03$ ). Generally, light drinks contain a lot of sweeteners. Several studies have shown that there is a positive correlation between the consumption of foods containing synthetic sweeteners and weight gain. Thus, Fowler and collaborators noted in 2008 [50] that the adult drinkers of lightened can in some cases present an over consumption of compensation, which can favor the risks of disordered eating behavior and lead to weight gain. This result agrees with that of the study SU.VI.MAX1 [51], carried out in France and which showed that consumers of foods and drinks with low sugar content had a higher average body mass index than that of non-consumers. This type of food encourages subjects to strongly increase the quantities consumed, in order to cover energy needs. In this case, this is a potential ineffective effect of light products which tend to "lure" the body. Normally, from the taste of the food, the brain memorizes its composition. This plays a role in adjusting the quantities to be consumed by the subject [52]. Several studies have shown that light products can maintain weight problems, as well as eating behavior disorders [53]. In addition, the consumption of diet drinks among school children has been associated with weight gain [54]. In contrast, conscious ingestion of aspartame was associated with increased overall energy intake [55]. On the other hand, long-term consumption of a mixture of sweeteners at a dose equivalent to that absorbed daily by some people can lead to changes in glucose metabolism, particularly in the brain [56].

\section{CONCLUSION}

It therefore appears from this study that the uncontrolled consumption of LP can cause eating disorders and increase the risk of overweight and obesity. Light products are not health foods, a light version may have fewer calories than the original food, but some light versions contain even more calories. However, these light foods can be eaten as part of a healthy diet, preferably in 
combination with a balanced and varied diet. It is also necessary to privilege those which have the least food additives possible. To lose weight effectively, you must therefore adopt the right eating habits and behaviors; eat slowly, balanced, varied and moderate. And practice an adapted physical activity.

\section{RECOGNITION}

Our thanks go to all the students who were kind enough to participate in the survey and to ensure that it ran smoot

\section{BIBLIOGRAPHIE}

1. Organisation Mondiale de la Santé (OMS). Commission sur les moyens de mettre fin à l'obésité de l'enfant appelle à prendre des mesures de haut niveau pour lutter contre un problème de santé majeur. 25 Janvier 2016.

Available from: https://www.who.int/end-childhood-obesity/news/launch-final-report/fr/

2. Ng M., Fleming T., Robinson M., Thomson B., Graetz N., Margono C., Gakidou E. Global, regional, and national prevalence of overweight and obesity in children and adults during 1980-2013: a systematic analysis for the Global Burden of Disease Study 2013. Lancet, 384(9945), pp. 766-781, 2014.

3. HCP (Haut Commissariat au plan). Les principaux points de l'intervention de M. Ahmed Lahlimi Alami, Haut-Commissaire au Plan à l'occasion de la présentation des résultats de l'Enquête Nationale sur l'Anthropométrie (ENA) réalisée en 2011 par la HCP.

Available on : https://www.hcp.ma/Les-principaux-points-de-l-intervention-de-M-Ahmed-Lahlimi-Alami-Haut-Commissaire-auPlan a1098.html

4. Medart J. Boysuel. Pratique de nutrition : l'alimentation préventive et curative. De Boeck Ed. Louvain-la-Neuve, Belgique. 296 p., 2009.

5. OMS (Organisation Mondiale de la Santé). Obésité : prévention et prise en charge de l'épidémie mondiale. Rapport d'une consultation de l'OMS (OMS, Série de Rapports techniques 894)._Editeurs: GENÈVE: Nombre de pages 284, 2003.

6. ICIS/CIHI (Institut Canadien d'Information sur la santé, Canadien Instute for health Information. Le surpoids et l'obésité au Canada. Une perspective de la santé de la population. Préparé par Kim D. Raine, 2004. Available on : https://secure.cihi.ca/free_products/CPHIOverweightandObesityAugust2004_f.pdf

7. Brunzell J.D., Davidson M., Furberg C.D., Goldberg R.B., Howard B.V., Stein J.H., \& Witztum, J. L. Lipoprotein management in patients with cardiometabolic risk: consensus statement from the American Diabetes Association and the American College of Cardiology Foundation. Diabetes Care, 31(4), pp. 811-822, 2008.

8. OMS (Organisation Mondial de la Santé) Obésité et surpoids, 2018. Available on : https://www.who.int/fr/news-room/fact-sheets/detail/obesity-and-overweight.

9. E Joanna Favre, R. Zwick Martine. Les perceptions sociales de l'alimentation et du corps chez les jeunes. Université de Fribourg, Département de Travail social et Politiques sociales Chaire francophone, 111pages, 2004.

10. Presnell, K., Bearboys, S. K., \& Stice, E. Risk factors for body dissatisfaction in adolescent boys and girls: A prospective study. International Journal of Eating Disorders, 36, pp. 389-401, 2004.

11. Thompson J. K., Heinberg L. J., Altabe M., \& Tantleff-Dunn S. Exacting Beauty: Theory, Assessment, and Treatment of Body Image Disturbance. Washington, DC: American Psychological Association. 396 pages, 1999.

12. Tremblay S., L'insatisfaction corporelle selon une approche de santé globale. Thèse de Doctorat en psychologie Docteur en psychologie (D. Psy.). Université de Laval. Quebec. Canada. 52 pages, 2017.

13. Fiske L., Fallon E., Blissmer B., \& Redding, C. Prevalence of body dissatisfaction among United States adults: Review and recommendations for future research. Eating Behaviors, 15(3), pp. 357-365, 2014.

14. Slevec, J. H., \& Tiggemann, M. Predictors of body dissatisfaction and disordered eating in middle-aged women. Clinical Psychology Review, 2011. 31(4), 515-24.

15. Clarisse M., Lafaille Paclet G., Cesarino Profico V., Giusti. Aliments et boissons allégés : qu'en penser ? Revue Médicale Suisse, Volume 8, 682-686, 2012.

16. Snrech L. M. Les produits laitiers allégés : Mirage ou panacée? Aspects Techniques et Nutritionnels. Thèse soutenue à l’Université Paul-Sabatier de Toulouse. 137pages, 2006.

17. ODAl. Ordonnance sur les denrées alimentaires. Edité Chancellerie fédérale, 2003.

18. Aldebert P. Light, additifs et chimie : pourquoi tant de haine ? L'actualité chimique, № 310, pp. 8-11, 2007. 
19. Nestle M. Food politics : how the food industry influences nutrition and health, Berkeley, CA, University of California Press. 2007.

20. Wansink B. and Chandon P. Can « low-fat » nutrition labels lead to obesity? Journal of Marketing Research, 43, pp. 605-617, 2006.

21. Ferreira C. The influence of food portion size and energy density on energy intake: implications for weight management, Journal of Risk Research, 9, 8, pp. 851-868, 2006.

22. Tabassum Zafar, Qayoom Naik AB and Vinoy K Srivastava. Aspartame: Effects and Awareness. Med Crave. Step into the World of research. MOJ Toxicology. 3(2), pp. 00046, 2017.

23. Amouyal C., F. Andreelli. Effets métaboliques des édulcorants. Réalités en nutrition et en diabétologie. 41, pp. 25-28, 2012.

24. Pouyat J. Le sucralose, l'édulcorant qui diminue la sensibilité à l'insuline. La nutrition, Bon à manger, Bon à savoir, 2018. Available from: https://www.lanutrition.fr/le-sucralose-ledulcorant-qui-diminue-la-sensibilite-a-linsuline

25. Marsh H. W., Richards G. E., Johnson S., Roche L., \& Tremayne P. Physical self-description questionnaire: psychometric properties and a multitrait-multimethod analysis of relations to existing instruments. Journal of Sport and Exercise psychology, 16, pp. 270-305, 1994.

26. Organisation Mondiale de la Santé. Obesity: Preventing and managing the Global Epidemic: report of a WHO Consultation on Obesity. Genève: WHO Technical Report Series 894. 2000.

Available on: https://www.who.int/nutrition/publications/obesity/WHO_TRS_894/en/

27. Rousseau A., S. Rusinek, M. Valls, S. Callahan. "Influences socioculturelles médiatiques et insatisfaction corporelle chez les adolescentes françaises." neuropsychiatrie de l'enfance et de l'adolescence, 59: pp. 163-168, 2011.

28. Moore DC. Body Image and Eating Behavior in Adolescent Girls. Am J Dis Child. Oct 1; 142(10), pp. 1114-1118, 1988.

29. Shroff H. and K. Thompson. "Peer influences, body image dissatisfaction, eating dysfunction and self-esteem in adolescent girls." Journal of Halth Psychology, 11(533), pp. 533-351, 2006.

30. HCP (Haut-Commissariat au plan) Les brefs du Plan Numéro 5. Filière laitière: situation et principales tendances Amal Boyssouri, Conjoncturiste, HCP. 2 pages. 2018. Available on : www.hcp.ma > file

31. Charby J, P. Hébel, S. Vaudaine, Les produits laitiers en France : évolution du marché et place dans la diète. Cahiers de nutrition et de diététique, 52S, S25-S34, 2017.

32. CREDOC. Rapport du groupe de travail PNNS sur les glucides Etapes 1 et 2 du mandat Ministère de l'Agriculture et de la Pêche Direction Générale de l'Alimentation Sous-direction de la réglementation, de la recherche et de la coordination des contrôles, 289 pages, 2007.

Available on: https://pdfs.semanticscholar.org/c023/0c70be1aa64204faae2fb5a26d0d242e0af1.pdf

33. Fardet A. Halte à l'aliment ultra transformé ! Mangeons vrai Broché. Thierry Souccar Edditions Vergeze, 256 pages, 2017.

34. Lemaizi S. Marché publicitaire. 2018, Une année A oublier. LesEco. ma. 2019.

Available from: https://leseco.ma/marche-publicitaire-2018-une-annee-a-oublier/

35. Kessou A. I. Chalamon. Représentations mentales de la consommation et des pratiques alimentaires : Approche par le carré sémiotique «bon/mauvais » La revue des Sciences de gestion. 3-4(º 261-262), pp. 51-58, 2013.

36. Perrin M.C. Mincir avec la méthode MG PEP'S. Aliments les conditions gagnantes. Edition Albin Michel, 304 pages, 2016.

37. Maillat J. et Wargnier H. Le mythe de l'allégé Les fausses promesses des produits light. Edition numérique Albin Michel, 2018.

38. Pacini F., Laffite A., et al : « La consommation de beurre allégé peut aider à réduire la ration lipidique alimentaire des diabétiques » Diabète et métabolisme, 1990, vol.16, p.21 (abstract). Cité dans la thèse Snrech L. M. Les produits laitiers allégés : Mirage ou panacée? Aspects Techniques et Nutritionnels. Thèse soutenue à l'Université Paul-Sabatier de Toulouse. 137pages, 2006.

39. Simon C. Alimentation et obésité. In : Pour une approche scientifique de l'obésité. Ed médicales et scientifiques, Elsevier, pp.65-77, 2003. 
40. Achour F. Perception des consommateurs vis-à vis des allégations nutritionnelles - Enquête réalisée au niveau de la commune de Sétif. Mémoire présenté pour l'obtention du diplôme de Magister en Sciences Alimentaires Option : Nutrition Humaine. Université Constantine 1, Institut de la Nutrition, de l'Alimentation et des Technologies Agro-Alimentaires (INATAA). Département de Nutrition. 157 pages, 2012.

41. Tiggemann, M. Socio cultural perspectives on human appearance and body image. In C. F. Cash \& L. Smolak (Eds.), Body image. A handbook of Science, Practice, and Prevention (pp. 12-19). New York, NY: The Guildford Press. 2011

42. Louis-Sylvestre J., Giachetti I., Mareschi J.P. «Les produits allégés : aspects physiologiques, nutritionnels, technologiques et réglementaires »Cah. Nutr. Diét., vol. 25, n¹, pp. 54-60, 1990.

43. Blundell J.E., Hill A.J., Rogers P.J. « Uncoupling sweetness and calories: methodological aspects of laboratory studies on appetite control » Appetite, vol. II (suppl.1), pp.54-61, 1988.

44. Fantino M. Peut-on tromper l'organisme avec des produits allégés? Cah Nutr Diet, 26, pp. 109-112, 1991.

45. Bellisle F., Rolland Cachera M.F., Deheeger M., et al. «Intake of low fat foods in a representative sample of the Paris area: anthropometric, nutritional, and socio-demographic correlates » J. Hum. Nutr. Diet., vol.7, pp. 335-346, 1994.

46. Bellisle F., Fricker J., Preziosi P. et al. «Consommation d'édulcorants intenses et attitudes alimentaires. Résultats d'un pré-test de l'étude SU.VI.MAX » Cah. Nutr. Diét., Vol. 32, N5, PP. 321-326, 1997.

47. Slama G. « Le plaisir sans le péché ? Ou la mode des aliments 'allégés’ » Cah. Nutr. Diét., vol.26, n², pp. 125-128, 1991.

48. Sarah S. Gul, A. Rebecca L. Hamilton, Alexander R. Munoz, Tanit Phupitakphol, Wei Liu, Sanjiv K. Hyoju, Konstantinos P. Economopoulos, Sara Morrison, Dong Hu, Weifeng Zhang, Mohammad Hadi Gharedaghi, Haizhong Huo, Sulaiboys R. Hamarneh, Richard A. Hodin. Inhibition of the gut enzyme intestinal alkaline phosphatase may explain how aspartame promotes glucose intolerance and obesity in mice. Applied Physiology, Nutrition, and Metabolism, 0, 0, 10.1139/apnm-0346, 2016.

49. Fagherazzi G, Vilier A, Saes Sartorelli D, Lajous M, Balkau B, Clavel-Chapelon F. Consumption of artificially and sugarsweetened beverages and incident type 2 diabetes in the Etude Epidemiologique auprès des femmes de la Mutuelle Génerale de l'Education Nationale-European Prospective Investigation into Cancer and Nutrition cohort. Am J Clin Nutr. 97(3), pp. 517-523, 2013.

50. Fowler SP, Williams K, Resendez RG, Hunt KJ, Hazuda HP, Stern MP. Fueling the obesity epidemic? Artificially sweetened beverage use and long-term weight gain. Obesity (Silver Spring, Md.), 16, pp.1894-1900, 2008.

51. Bellisle F., M.A. Altenburg de Assis, B. Fieux P., Preziosi P., Galan, B. Guy-Grand \& S. Hercberg. "Use of "light" foods and drinks in French adults: biological, anthropometric and nutritional correlates. J. Hum. Nutr. Diet. 14, pp. 191-206, 2001.

52. CEDUS. Plusieurs travaux ont montré que les produits allégés peuvent entretenir les problèmes de poids, ainsi que les troubles du comportement alimentaire, 2005.

53. Zermati J.P. La fin des régimes. Hachette Paris, 263 pages, 1998.

54. Blum J.W, Jacobsen D.J, Donnelly J.E. Beverage consumption patterns in elementary school aged children across a two-year period. J Am Coll Nutr. 24, pp. 93-98, 2005.

55. Mattes R. Effects of aspartame and sucrose on hunger and energy intake in huboyss. Physiol Behav. 47, pp. 1037-1044, 1990.

56. Lemke C, Les édulcorants de synthèse modifieraient les réseaux de neurones du cerveau. Sciences et Avenir. 2019.

AVAILABLE ON : HTTPS://WWW.SCIENCESETAVENIR.FR/SANTE/CERVEAU-ET-PSY/LES-EDULCORANTS-MODIFIENT-LES-RESEAUX-DENEURONES-DU-CERVEAU_135918 